Journal of Marine Science and Technology; Vol. 17, No. 3; 2017: 301-311

DOI: $10.15625 / 1859-3097 / 17 / 3 / 8698$

http://www.vjs.ac.vn/index.php/jmst

\title{
CHARACTERISTICS OF MARINE ENVIRONMENTAL GEOCHEMISTRY FROM NGA SON TO CUA HOI, THANH HOA PROVINCE (0-30 METERS WATER DEPTH)
}

\author{
Luong Le Huy ${ }^{1}$, Mai Trong Nhuan', Le Van $\mathrm{Hoc}^{3}$, Trinh Nguyen Tinh ${ }^{3}$, Le Anh Thang ${ }^{3}$, \\ Nguyen Van Ha ${ }^{1}$, Hoang Van Tuan ${ }^{1}$, Nguyen Tai Tue ${ }^{2}$, Tran Dang Quy ${ }^{1,2 *}$ \\ ${ }^{1}$ Sea and Island Research Center, Hanoi University of Science, VNU \\ ${ }^{2}$ Faculty of Geology, Hanoi University of Science, VNU \\ ${ }^{3}$ Marine Natural Ressources, Environment Survey Center \\ *E-mail: quytrandang@gmail.com
}

Received: 16-9-2016

\begin{abstract}
The aim of this study is to clarify characteristics of marine environmental geochemistry from Nga Son to Cua Hoi (0-30 m water depth). The water and sediment samples were collected from March to April of each year during the period 2011 - 2013. Results indicated that salinity of seawater ranged from $1.2 \%$ to $33.3 \%$. The seawater environment was classified into neutral-weak oxidation in the layer from $0-10 \mathrm{~m}$ water depth and weak alkaline-weak oxidation in the layer 10-30 m water depth. Concentrations of most anions and elements in seawater had a decreasing trend from nearshore to offshore regions and with depth, with the exception of $\mathrm{SO}_{4}{ }^{2-}$, $\mathrm{CO}_{3}{ }^{2-}, \mathrm{Mg}, \mathrm{B}^{-}, \mathrm{Br}^{-}, \mathrm{I}^{-}$. Sedimentary environment was highly dominated by neutral-strong oxidization and weak alkaline-weak oxidization for the zone from 0-10 m water depth and 10-30 m water depth, respectively. Concentrations of anions and elements tended to be higher in nearshore region than those in offshore zone, with the exception of $\mathrm{SO}_{4}{ }^{2-}, \mathrm{PO}_{4}{ }^{3-}, \mathrm{NO}_{3}{ }^{-}$and positively correlated with finegrained sediment compositions. Total PCBs concentration increased from north to south, yet $\mathrm{HCHs}$ and DDTs had opposite trends. Compared with environmental quality guidelines, marine sediments and seawater were not polluted by heavy metals and organic compounds of PCBs and OCBs.
\end{abstract}

Keywords: Environmental geochemistry, seawater, marine sediments, heavy metal, organic compounds, Nga Son.

\section{INTRODUCTION}

The study area is located in the sea area from Nga Son - Cua Hoi (0-30 m water depth) with an inner boundary being the coastline and outer boundary being a depth contour of $30 \mathrm{~m}$ (fig. 1). Characteristics of the study area can be distinguished between the zones $0-10 \mathrm{~m}$ and 10-30 $\mathrm{m}$ water depth and influenced by freshwater flows of Day, Lach Sung, Lach Truong, Hoi estuaries. The main human activities are fishery and marine transportation that can influence marine environment. The coastline has some large ports such as Nghi Son and Le Mon ports. The maritime transport may increase the risk in marine pollution by oils. Additionally, human activities in mainland, including agriculture, industry, tourism can impact the geochemical environment of the study area.

Seawater temperature ranges from $26-28^{\circ} \mathrm{C}$ and $21-23^{\circ} \mathrm{C}$ for summer and winter, respectively. The surface currents annually 
flow with a direction from north to south in both summer and winter, similar to the current in Gulf of Tonkin. The flow velocity is 20$25 \mathrm{~cm} / \mathrm{s}$ during the winter, being stronger than that during the summer due to northeast monsoon's influence. The sea currents flow toward southwest in the north region and southeast in the south region. The study area is located at transitional environment between diurnal tide and mixed diurnal tide with the highest tidal amplitude reaching to $3.0 \mathrm{~m}$.
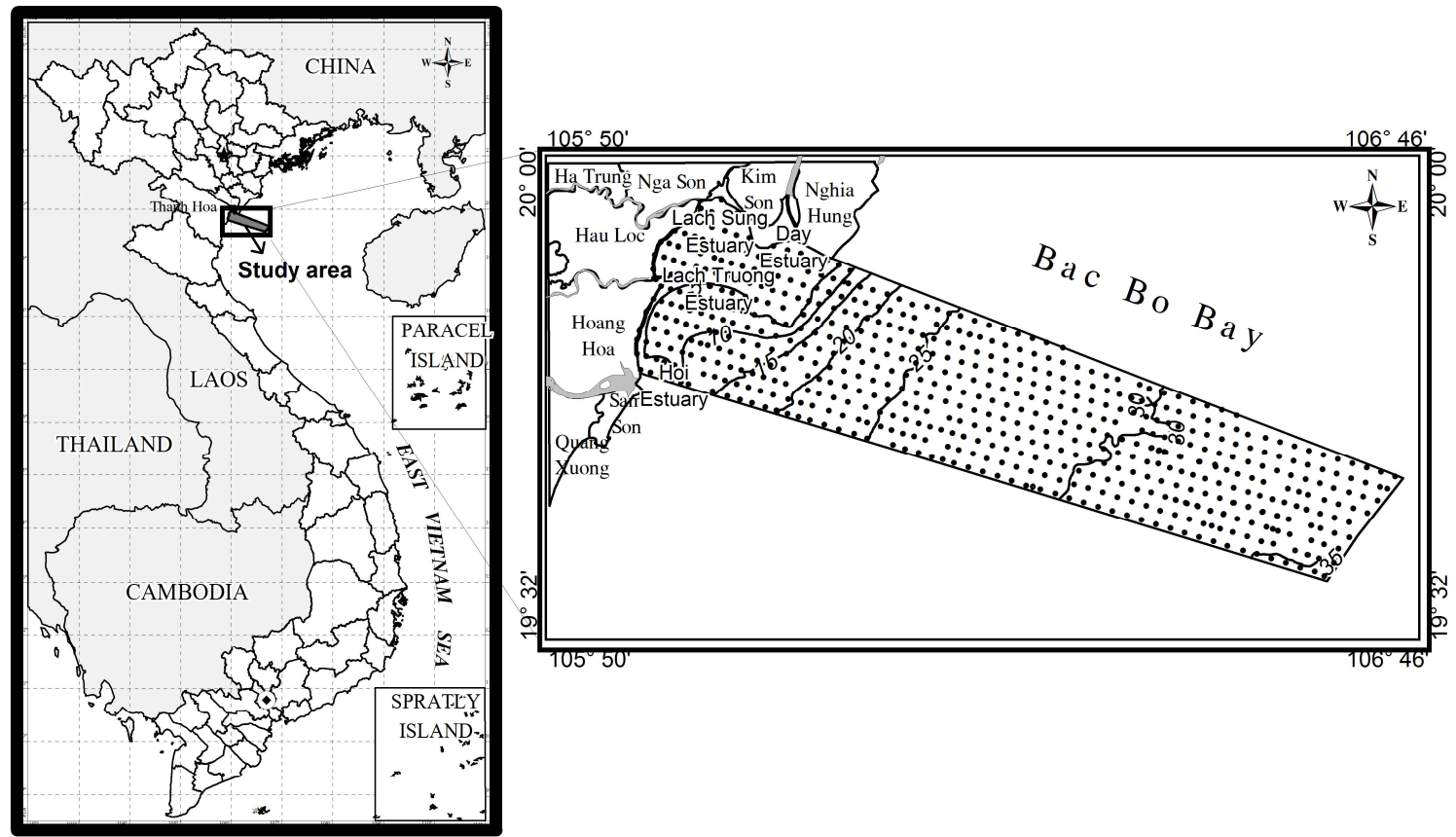

Fig. 1. Map shows the location of the sea area from Nga Son-Cua Hoi (0-30 m water depth) and sampling sites, dots are sampling sites of water and sediment samples

Human activities on the mainland often cause many influences on the marine environment, particularly the coastal zone in the developing countries [1-3]. Marine pollution by heavy metals, polychlorinated biphenyls (PCBs) and organochlorine pesticides (OCPs) is a serious problem for human being due to their bioaccumulation into organisms and human bodies through the close relationship in food chains and food webs [46]. Therefore, study on characteristics of heavy metal and organic compound concentrations in marine environments will provide crucial information for monitoring the land-based pollution and protecting the marine ecosystems. In recent decades, many geochemical environment researches have been widely conducted to understand the origin of organic matters in seawater and marine sediments [7], geochemical characteristics [8], to assess the seawater and marine sediment quality, particularly the trace element contaminations in the nearshore region [4, 9-11] and coastal gulfs $[12,13]$.

In Vietnam, environmental geochemistry researches have been integrated in several basic marine geological research programs of Marine Natural Resources - Environment Survey Center such as Research on the potential accumulation of pollutants in coastal sediment in Vietnam. However, the marine environmental geochemistry of Nga Son - Cua Hoi (0-30 m water depth) has not been reported in detail. Therefore, the purposes of this study are to examine the marine environmental geochemistry characteristics of seawater and sediments of Nga Son - Cua Hoi (0-30 m water depth). The results from this study provide 
important baseline data for assessing the status and monitoring the marine environmental quality.

\section{MATERIALS AND METHODS}

\section{Fieldwork and sampling}

The fieldwork was conducted from March to April of each year in the period 2011-2013 in the sea area from Nga Son to Cua Hoi (0-30 m water depth). Seawater samples were collected from surface and bottom layers from 140 sites (fig. 1) using a Niskin bottle for $\mathrm{pH}$, Eh, COD, $\mathrm{BOD}_{5}$ and heavy metals $\mathrm{Cu}, \mathrm{Pb}, \mathrm{Zn}, \mathrm{Sb}, \mathrm{As}$, $\mathrm{Hg}$.

Sediment samples were collected from 117 sites for $\mathrm{pH}$, Eh analysis; 77 sites for $\mathrm{B}, \mathrm{Br}, \mathrm{I}$ and carbonate analysis; 96 sites for elemental $(\mathrm{Cu}, \mathrm{Pb}, \mathrm{Zn}, \mathrm{Sb}, \mathrm{As}, \mathrm{Hg})$ analysis; 526 sites for sediment grain size analysis; 32 sites for iron ion and 10 sites for PCBs and OCPs. Sediment samples were collected using an ocean grab sampler at offshore sites and a gravity corer at Day, Lach Sung and Lach Truong estuaries. The core samples were sliced into interval of $20 \mathrm{~cm}$ from top to bottom. All samples were immediately kept in cool boxes and then transported to laboratory for processing and analyzing at Marine Natural Resources Environment Survey Center.

\section{Sample analysis}

In laboratory, Eh, $\mathrm{pH}$ and salinity of seawater samples were measured using the $\mathrm{Eh}, \mathrm{pH}$ and salinity meters, respectively. The $\mathrm{Mn}, \mathrm{B}$, $\mathrm{Br}, \mathrm{I}, \mathrm{PO}_{4}^{3-}, \mathrm{NO}_{3}{ }^{-}, \mathrm{SO}_{4}{ }^{2-}$ concentrations were determined using UV-VIS spectrophotometer. The $\mathrm{K}, \mathrm{Na}, \mathrm{Cu}, \mathrm{Pb}, \mathrm{Zn}, \mathrm{Sb}, \mathrm{As}, \mathrm{Hg}$ concentrations were analyzed using an atomic absorption spectroscopy. The OCPs and PCBs concentrations were analyzed using a gas chromatography mass spectrometry. PCBs congeners are PCB 28, PCB 52, PCB 101, PCB 118, PCB 153, PCB 138 and PCB 180. OCPs congeners are $\mathrm{HCHs}(\alpha \mathrm{HCH}, \beta \mathrm{HCH}, \delta \mathrm{HCH}$, $\gamma \mathrm{HCH}$ ) and DDTs (44DDT, 44DDD, 44DDE). The sediment grain size composition was measured by both sieve and pipette methods. The $\mathrm{BOD}_{5}$ concentrations were analyzed by using $\mathrm{Na}_{2} \mathrm{~S}_{2} \mathrm{O}_{3} 0.025 \mathrm{~N}$ for dilution, incubation and titration (TCVN 6001-1: 2008) [18]. The COD concentrations were analyzed by dichromate upstream method (TCVN 6491: 1999) [19]. The $\mathrm{CO}_{3}{ }^{2-}$ was determined by phenolphthalein after titrating with $0.1 \mathrm{M} \mathrm{HCl}$. For analyzing, sediment samples were digested using microwave by three methods $(2 \mathrm{ml}$ of $65 \% \mathrm{HNO}_{3}, 5 \mathrm{ml}$ of $37 \% \mathrm{HCl}$ and $1 \mathrm{ml}$ of $\mathrm{HF}$ $40 \%$ ) after being dried and comminuted to fine size (TCVN 6649: 2000) [20].

\section{Environmental quality assessment}

Talasofil coefficient (Ta) and concentration factor (Td) were used to evaluate the concentration level of elements in the seawater and marine sediments, respectively. Both the $\mathrm{Ta}$ and $\mathrm{Td}$ were calculated by a ratio of mean concentration of the chemical element and its concentration in the world mean concentration. Base on $\mathrm{Ta}$ and $\mathrm{Td}$, chemical elements were divided into 3 groups: The less concentrated elements $(\mathrm{Ta}, \mathrm{Td}<1)$; the weak concentrated elements $(1 \leq \mathrm{Ta}, \mathrm{Td}<2)$; the strong concentrated elements ( $\mathrm{Ta}, \mathrm{Td} \geq 3$ ) [17].

The seawater and marine sediment qualities were evaluated using National technical regulation on marine water quality (QCVN 10MT:2015/BTNMT) [14], sediment quality (QCVN 43:2012/BTNMT) [15] and Canadian sediment quality guideline [16]. Spatial variation of the geochemical parameters was presented using MapInfo software.

\section{RESULTS AND DISCUSSION}

\section{Characteristics of marine surfacial sediments}

Sediments varied from fine- to coarsegrained sizes. According to the absorbed capacities of sediments to toxic substances, surface sediments could be divided into three groups [17]: 1) Low absorbed capacity; 2) Medium absorbed capacity; and 3) High absorbed capacity (fig 2). The first sediment group composed less than $20 \%$ of the finegrained fraction and major component of sand (90.2\%). This sediment type was distributed from $1 \mathrm{~m}$ to $3 \mathrm{~m}$ in depth of some estuaries and marine areas that were greater than $30 \mathrm{~m}$ water depth. The second sediment type had finegrained fraction ranging from $20 \%$ to $60 \%$ and 
the residue was sandy sediments. This sediment type was mainly distributed from 29-30 m water depth and some small areas in 3-9 m water depth. The main components of this group included $10.6 \pm 3.9 \%$ clay, $25.1 \pm 7.3 \%$ silt, $63.5 \pm 8.9 \%$ sand. The last sediment type had fine-grained fraction greater than $60 \%$, and was mainly distributed from 10-29 m water depth. The main components were $32.6 \pm$ $11.0 \%$ of clay, $57.3 \pm 9.4 \%$ of silt, and $10.1 \pm$ $11.2 \%$ of sand.

\section{Marine environmental geochemistry}

\section{Seawater environment}

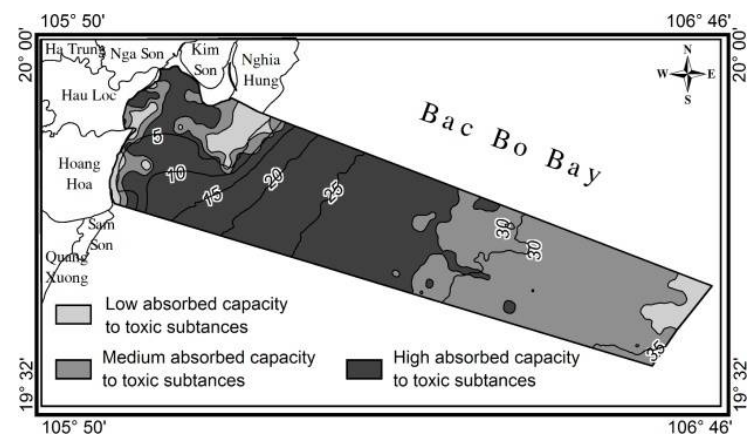

Fig. 2. Spatial distribution of three types of surficial sediments that have different absorbed capacities to toxic substances in the sea area from Nga Son to Cua Hoi (0-30 m water depth)

Mean value of salinity was $25.1 \%$ and different between 0-10 $\mathrm{m}$ and $10-30 \mathrm{~m}$ water depth zones. Mean salinity was $8.8 \%$ and $31.1 \%$ for the shallow and offshore zones, respectively. Salinity tended to increase with depth and distance from the shoreline. Results indicated that the region of $0-10 \mathrm{~m}$ water depth was influenced by freshwater flows from Day, Lach Truong, Lach Sung, and Ma rivers. Mean values of $\mathrm{pH}$ and $\mathrm{Eh}$ were 7.99 and $126 \mathrm{mV}$, respectively and tended to less vary with depth. However, $\mathrm{pH}$ had an increasing trend from shoreline to offshore region and Eh had an opposite trend, being higher and lower in the offshore and nearshore regions, respectively. $\mathrm{pH}$ and Eh values showed that seawater was categorized as weak alkaline-weak oxidation environment in the region of $10-30 \mathrm{~m}$ water depth and neutral-weak oxidation in the region of $0-10 \mathrm{~m}$ water depth [17]. The COD and
$\mathrm{BOD}_{5}$ values ranged from 2.2-4.2 $\mathrm{mgO}_{2} / \mathrm{l}$ and 1.4-2.4 $\mathrm{mgO}_{2} / 1$, respectively. The small difference between $\mathrm{COD}$ and $\mathrm{BOD}_{5}$ values indicated that suspended organic matter in seawater was composed mainly of biodegradable organic materials (i.e., phytoplankton) [17].

The major anions $\mathrm{SO}_{4}{ }^{2-}$ and $\mathrm{NO}_{3}{ }^{-}$were distributed relatively uniformly in seawater with variation coefficients being $40.7 \%$ and $42.0 \%$, respectively. $\mathrm{CO}_{3}{ }^{2-}$ concentration was distributed relatively unevenly with a variation coefficient of $64.7 \%$. The average concentration of $\mathrm{SO}_{4}{ }^{2-}$ was $1,928 \mathrm{mg} / \mathrm{l}$, higher than that in seawater from Mong Cai to Deo Ngang region $(1,085 \mathrm{mg} / \mathrm{l})$. The average concentration of $\mathrm{NO}_{3}{ }^{-}$was $0.87 \mathrm{mg} / \mathrm{l}$, similar to that in seawater from Mong Cai to Deo Ngang region. The average concentration of $\mathrm{CO}_{3}{ }^{2-}$ was $7.1 \mathrm{mg} / \mathrm{l}$, lower than that in seawater from Mong Cai - Deo Ngang region [21]. Both $\mathrm{SO}_{4}{ }^{2-}$ and $\mathrm{CO}_{3}{ }^{2-}$ concentrations tended to increase with depth and increase from the shoreline to offshore area. $\mathrm{NO}_{3}{ }^{-}$concentration had an opposite trend compared with $\mathrm{CO}_{3}{ }^{2-}$ and tended to decrease with depth and towards offshore region. The mean concentration, the variation coefficient and the Ta of chemical elements in seawater from Nga Son to Cua Hoi (0-30 m water depth) are showed in table 1 . The Ta values of $\mathrm{Mg}, \mathrm{B}, \mathrm{Br}$ and $\mathrm{I}$ were less than 1 , classified as less concentrated elements in seawater. The variation coefficients of these elements ranged from 39.4-40.9\%, indicating that they were distributed relatively uniformly in the seawater. All of these chemical elements tended to increase with depth and from coastline to offshore region.

The Ta values of heavy metals $\mathrm{Mn}, \mathrm{Cu}, \mathrm{Zn}$, $\mathrm{Cd}, \mathrm{Sb}$, As and $\mathrm{Hg}$ ranged between 1-2, indicating that they were weak concentrated elements in seawater. In which, $\mathrm{Sb}$ and As distributed very uniformly with the variation coefficients of $15.5 \%$ and $15.6 \%$, respectively; $\mathrm{Cu}, \mathrm{Zn}, \mathrm{Cd}$ and $\mathrm{Hg}$ were evenly distributed in seawater with respective variation coefficients of 34.3, 29.8, 22.3 and $36.7 \%$, and $\mathrm{Mn}$ distributed relatively uniformly with the variation coefficient of $49.7 \%$. All these elements decreased with depth and from nearshore region to offshore region. 
Table 1. Statistical concentration (mg/l) and Talasofil coefficient $(\mathrm{Ta})$ of selected elements in seawater from Nga Son to Cua Hoi Sea (0-30 m water depth) $(n=127)$

\begin{tabular}{|c|c|c|c|c|c|c|}
\hline & $\mathrm{Cm}(\mathrm{s} 0-10)$ & $\mathrm{Cm}(\mathrm{s} 10-30)$ & $\mathrm{Cm}(\mathrm{b} 10-30)$ & $\mathrm{Cm}$ & V (\%) & $\mathrm{Ta}$ \\
\hline $\mathrm{Mg}$ & 317 & 1,123 & 1,187 & 957 & 40.2 & 0.71 \\
\hline $\mathrm{Sb}$ & 0.00055 & 0.00052 & 0.00049 & 0.00052 & 15.5 & 1.03 \\
\hline As & 0.0041 & 0.0037 & 0.0035 & 0.0037 & 15.6 & 1.23 \\
\hline I & 0.015 & 0.057 & 0.056 & 0.043 & 39.7 & 0.71 \\
\hline B & 1.04 & 3.89 & 4.11 & 3.30 & 40.7 & 0.72 \\
\hline $\mathrm{Br}$ & 16.2 & 54.7 & 57.9 & 46.8 & 39.4 & 0.72 \\
\hline $\mathrm{Mn}$ & 0.0060 & 0.0028 & 0.0024 & 0.0034 & 49.7 & 1.69 \\
\hline $\mathrm{Cu}$ & 0.0059 & 0.0034 & 0.0032 & 0.0039 & 34.3 & 1.3 \\
\hline $\mathrm{Zn}$ & 0.025 & 0.018 & 0.016 & 0.019 & 29.8 & 1.88 \\
\hline $\mathrm{Cd}$ & 0.00023 & 0.00019 & 0.00018 & 0.00020 & 22.3 & 1.97 \\
\hline $\mathrm{Hg}$ & 0.00007 & 0.00004 & 0.00003 & 0.00004 & 36.7 & 1.46 \\
\hline $\mathrm{Pb}$ & 0.00058 & 0.00028 & 0.00027 & 0.00029 & 40.1 & 11.88 \\
\hline
\end{tabular}

Note: $\mathrm{Cm}(\mathrm{s} 0-10), \mathrm{Cm}(\mathrm{s} 10-30), \mathrm{Cm}(\mathrm{s} 10-30)$ and $\mathrm{Cm}$ are the mean concentrations in surface layer of 0-1 m water depth, surface layer in 10-30 m water depth, bottom layer in 10-30 m water depth and whole study area, respectively; $V$ is variation coefficient.

The Ta value of $\mathrm{Pb}$ was 11.88 , being strong concentrated element in seawater. $\mathrm{Pb}$ concentration was distributed relatively uniformly in seawater with the variation coefficient of $40.1 \%$ (fig. 3). The $\mathrm{Pb}$ concentration slightly decreased with depth and from nearshore to offshore regions, being $0.28 .10^{-3} \mathrm{mg} / \mathrm{l}$ and $0.27 .10^{-3} \mathrm{mg} / \mathrm{l}$ for the surface and bottom layer in $10-30 \mathrm{~m}$ water depth, respectively and $0.58 .10^{-3} \mathrm{mg} / \mathrm{l}$ in $0-10 \mathrm{~m}$ water depth zone.

\section{Marine sediment environment}

The mean values of $\mathrm{pH}$ and Eh parameters of sediments were 8.76 and $150 \mathrm{mV}$, respectively. The $\mathrm{pH}$ ranged from 6.84 to 8.08 and $\mathrm{Eh}$ ranged from $107 \mathrm{mV}$ to $223 \mathrm{mV}$. Geochemical environment of sediments was divided into neutral-strong oxidation in $0-10 \mathrm{~m}$ water depth zone and weak alkaline-weak oxidation in 10-30 $\mathrm{m}$ water depth zone. The coefficients $\mathrm{K}_{1}, \mathrm{~K}_{2}, \mathrm{~K}_{3}, \mathrm{~K}_{4}$ and $\mathrm{K}_{5}$ ranged from $0.51-4.59,0.10-0.62,0.05-0.50,0.29-0.85$ and $0-2.45$, respectively, indicating that sedimentary environment was characterized by the oxidation and dominated accumulation of biological and chemical carbonate [17].

The major anion concentrations greatly varied in the marine sediments (table 2): $\mathrm{SO}_{4}{ }^{2-}$, $\mathrm{PO}_{4}{ }^{3-}$ and $\mathrm{NO}_{3}{ }^{-}$concentrations displayed a uniform variation with the variation coefficients ranging from 22.9-32.9\% and $\mathrm{CO}_{3}{ }^{2-}$ concentration unevenly distributed with variation coefficient of $93.0 \%$. $\mathrm{SO}_{4}{ }^{2-}, \mathrm{PO}_{4}{ }^{3-}$ and $\mathrm{NO}_{3}{ }^{-}$concentrations was tended to be higher in the southeast and central regions of the study area and lower in the northeast and west regions. In the northeast, the concentrations of those anions seemed to be lower than in the west region. The concentrations of major anions positively correlated with fine-grained sediment fraction $(\mathrm{r}=0.57-0.60) . \mathrm{CO}_{3}{ }^{2-}$ concentration tended to be higher in the western region, and lower in the eastern region of the study area. The $\mathrm{CO}_{3}{ }^{2-}$ concentration negatively correlated with the fine-grained sediment fraction $(\mathrm{r}=-0.77)$ (table 2$)$. In comparison with to the marine sediments from Mong Cai to Deo Ngang area [21], the concentrations of $\mathrm{PO}_{4}{ }^{3-}, \mathrm{NO}_{3}{ }^{-}$and $\mathrm{CO}_{3}{ }^{2-}$ were higher, but the concentration of $\mathrm{SO}_{4}{ }^{2-}$ was relatively lower.

Based on concentration factor (Td), the elements could be classified into three groups: 1) The less concentrated elements $(\mathrm{Td}<1)$ were $\mathrm{Mn}, \mathrm{Zn}, \mathrm{Pb}, \mathrm{Cu}, \mathrm{Sb}$ and As; 2) The weak concentrated elements $(1 \leq \mathrm{Td}<2)$ were $\mathrm{Hg}$ and $\mathrm{B} ; 3)$ The strong concentrated elements $(\mathrm{Td} \geq 3)$ were $\mathrm{Br}$ and $\mathrm{I}$. The concentrations of $\mathrm{Br}$ and $\mathrm{I}$ showed the neutral variation in marine environment due to their bioavailability in marine organisms [17]. 


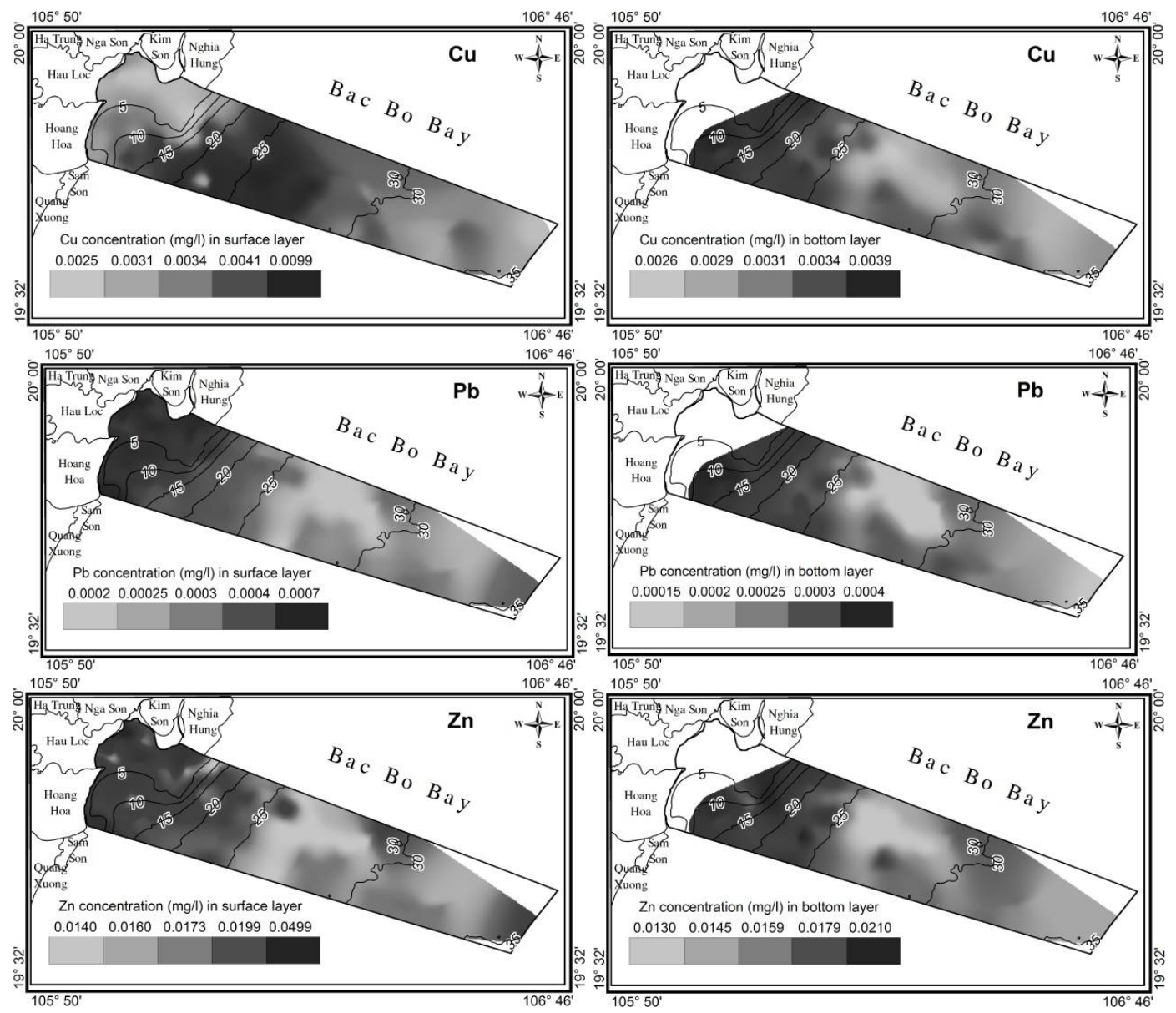

Fig. 3. Spatial distribution of selected metal concentrations in different seawater layers from Nga Son to Cua Hoi

Table 2. Statistical parametric concentration and $\mathrm{Td}$ coefficient of selected elements in marine sediments from Nga Son - Cua Hoi Sea (0-30 m water depth) $(\mathrm{n}=68)$

\begin{tabular}{|c|c|c|c|c|c|c|c|c|}
\hline & Unit & Cmax & Cmin & Cmean & V (\%) & HLTBTG & Td & $r$ \\
\hline $\mathrm{Mn}^{2+}$ & $\%$ & 0.095 & 0.008 & 0.043 & 47.0 & 0.085 & 0.50 & 0.83 \\
\hline $\mathrm{Zn}^{2+}$ & $10^{-3} \%$ & 0.93 & 0.12 & 0.59 & 39.0 & 2 & 0.29 & 0.30 \\
\hline $\mathrm{Pb}^{2+}$ & $10^{-3} \%$ & 0.68 & 0.18 & 0.50 & 23.0 & 2 & 0.25 & 0.58 \\
\hline $\mathrm{Cu}^{2+}$ & $10^{-3} \%$ & 0.57 & 0.06 & 0.34 & 42.2 & 4 & 0.09 & 0.44 \\
\hline $\mathrm{Sb}^{3+}$ & $10^{-3} \%$ & 0.033 & 0.012 & 0.024 & 19.8 & 0.14 & 0.17 & 0.61 \\
\hline $\mathrm{As}^{3+}$ & $10^{-3} \%$ & 0.15 & 0.02 & 0.08 & 32.7 & 0.1 & 0.76 & 0.57 \\
\hline $\mathrm{Hg}^{2+}$ & $10^{-3} \%$ & 0.012 & 0.002 & 0.006 & 30.9 & 0.003 & 1.83 & 0.44 \\
\hline $\mathrm{SO}_{4}{ }^{2-}$ & $\%$ & 0.037 & 0.008 & 0.024 & 22.9 & & & 0.59 \\
\hline $\mathrm{PO}_{4}{ }^{3-}$ & $\%$ & 0.040 & 0.010 & 0.025 & 26.8 & & & 0.57 \\
\hline $\mathrm{NO}_{3}{ }^{-}$ & $\%$ & 0.016 & 0.002 & 0.009 & 32.9 & & & 0.60 \\
\hline $\mathrm{CO}_{3}{ }^{2-}$ & $\%$ & 5.64 & 0.11 & 1.75 & 93.0 & & & -0.77 \\
\hline $\mathrm{B}^{-}$ & $10^{-3} \%$ & 4.5 & 0.7 & 2.3 & 45.2 & 2 & 1.17 & 0.46 \\
\hline $\mathrm{Br}^{-}$ & $10^{-3} \%$ & 5.5 & 0.9 & 3.1 & 37.8 & 0.6 & 6.3 & 0.45 \\
\hline $\mathrm{I}$ & $10^{-3} \%$ & 2.6 & 0.5 & 1.4 & 33.4 & 0.11 & 12.74 & 0.45 \\
\hline
\end{tabular}

Note: Cmax, Cmin, Cmean are the maximum, minimum, average concentrations, respectively; $\mathrm{V}$ is variation coefficient; HLTBTG is the world average concentration [17]; $r$ is correlation coefficient with fine-grained sediment fraction. 
Concentrations of $\mathrm{Zn}, \mathrm{Pb}, \mathrm{As}, \mathrm{Hg}, \mathrm{Br}$ and $\mathrm{I}$ were evenly distributed in marine sediments with the variation coefficients of $23.0-39.0 \%$. $\mathrm{Sb}$ concentration was distributed highly uniformly with variation coefficient of $19.8 \%$ and concentrations of $\mathrm{Mn}, \mathrm{Cu}$ and $\mathrm{B}$ were distributed relatively uniformly with variation coefficients being $>40 \%$ (fig. 4 ). The variation trend of these elements was quite similar to the trend of fine-grained sediment distribution $(\mathrm{r}=$ $0.30-0.83$ ). In comparison with to the marine sediments from Mong Cai to Deo Ngang area [21], the concentrations of these chemical elements were lower, with the exception of concentrations of $\mathrm{B}, \mathrm{Mn}, \mathrm{Zn}$ and $\mathrm{Br}$.

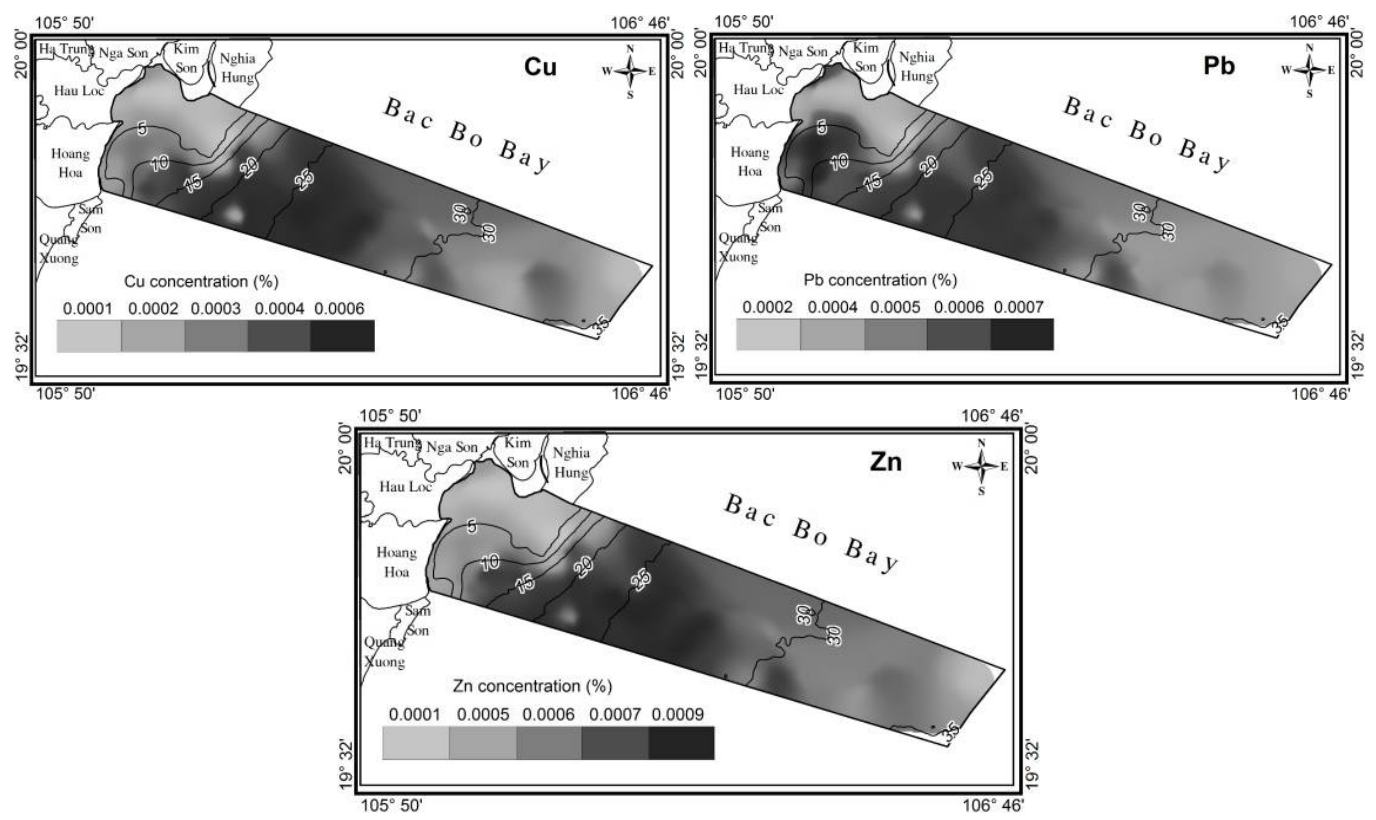

Fig. 4. Spatial distribution of selected heavy metals in marine sediments from Nga Son to Cua Hoi

In sediments, PCBs, HCHs and DDTs contents ranged from $4.37 \mathrm{ng} / \mathrm{g}$ to $9.27 \mathrm{ng} / \mathrm{g}$ (median: $6.65 \mathrm{ng} / \mathrm{g}$ ); 0.04-0.11 ng/g (median: $0.09 \mathrm{ng} / \mathrm{g}$ ) and $0.31-0.65 \mathrm{ng} / \mathrm{g}$ (median: 0.48 ng/g), respectively (table 3, 4). Among PCBs congeners, PCB 138 was detected at the highest concentration, with a range of 13.9-37.8\%. Similarly, $\gamma \mathrm{HCH}$ was the most dominant congener of OCPs. For DDTs, p,p' DDT content was the highest congener. For PCBs, congener $6 \mathrm{Cl}$ was the most dominant, ranging from $2.80-6.80 \mathrm{ng} / \mathrm{g}$ with a mean of $4.61 \mathrm{ng} / \mathrm{g}$. Total PCBs content tended to increase from north to south, reaching the highest concentration of $7.81 \mathrm{ng} / \mathrm{g}$ in Lach Truong estuary. HCHs and DDTs contents tended to decrease towards the south region, reaching the lowest content of $0.04 \mathrm{ng} / \mathrm{g}$ in Lach Truong estuary.
PCBs, HCHs and DDTs concentrations had different variation trends with depth. At Day estuary, PCBs, HCHs and DDTs concentrations increased from surface sediment to bottom of core, reaching the highest value of 6.65 at the depth of 40-60 cm. At Lach Sung estuary, PCBs and DDTs concentrations tended to increase with depth and $\mathrm{HCHs}$ remained unchanged with depth. The highest PCBs and DDTs concentrations were found at sediment layer from $20-40 \mathrm{~cm}$ in depth with respective concentrations of $8.64 \mathrm{ng} / \mathrm{g}$ and $0.60 \mathrm{ng} / \mathrm{g}$. At Lach Truong estuary, PCBs concentration tended to increase with the depth, while $\mathrm{HCH}$ and DDTs concentrations had opposite trends. The highest PCBs concentration of $9.72 \mathrm{ng} / \mathrm{g}$ was found in sediment layer from $20-40 \mathrm{~cm}$ in depth. HCHs and DDTs concentrations were $0.11 \mathrm{ng} / \mathrm{g}$ and $0.65 \mathrm{ng} / \mathrm{g}$ in sediment layer from $55-75 \mathrm{~cm}$ in depth. 
Table 3. The PCB congener concentration (ng/g) in estuary sediments from Nga Son to Cua Hoi $(\mathrm{n}=9)$

\begin{tabular}{|c|c|c|c|c|c|c|c|}
\hline Congener & Cmin & Cmax & Cmean & Congener & Cmin & Cmax & Cmean \\
\hline Total $2 \mathrm{Cl}$ & 0.04 & 0.35 & 0.11 & PCB 28 & 0.26 & 1.15 & 0.59 \\
\hline Total 3Cl & 0.26 & 1.15 & 0.59 & PCB 52 & 0.08 & 0.96 & 0.28 \\
\hline Total 4Cl & 0.14 & 3.50 & 0.74 & PCB 101 & 0.00 & 0.04 & 0.02 \\
\hline Total $5 \mathrm{Cl}$ & 0.14 & 0.34 & 0.23 & PCB 118 & 0.02 & 0.05 & 0.03 \\
\hline Total 6Cl & 2.80 & 6.80 & 4.61 & PCB 153 & 1.05 & 1.90 & 0.48 \\
\hline Total 7CI & 0.12 & 0.42 & 0.29 & PCB 138 & 1.15 & 2.40 & 1.82 \\
\hline Total $8 \mathrm{Cl}$ & 0.14 & 0.45 & 0.29 & PCB 180 & 0.08 & 0.21 & 0.16 \\
\hline Total 9Cl & 0.01 & 0.26 & 0.11 & Total PCBs & 4.37 & 9.27 & 6.97 \\
\hline Total $10 \mathrm{Cl}$ & 0.00 & 0.03 & 0.01 & & & & \\
\hline
\end{tabular}

Table 4. Concentrations of OCP congeners ( $\mathrm{ng} / \mathrm{g})$ in marine sediments from Nga Son to Cua Hoi $(n=9)$

\begin{tabular}{|c|c|c|c|c|}
\hline & $\alpha \mathrm{HCH}$ & $\gamma \mathrm{HCH}$ & $\beta \mathrm{HCH}$ & $\delta \mathrm{HCH}$ \\
\hline Cmin & 0.01 & 0.01 & 0.00 & 0.04 \\
\hline Cmax & 0.02 & 0.06 & 0.05 & 0.11 \\
\hline \multirow[t]{2}{*}{ Cmean } & 0.02 & 0.04 & 0.02 & 0.08 \\
\hline & 44DDE & 44DDD & 44DDT & \\
\hline Cmin & 0.00 & 0.1 & 0.18 & \\
\hline Cmax & 0.12 & 0.25 & 0.37 & \\
\hline Cmean & 0.04 & 0.17 & 0.28 & \\
\hline
\end{tabular}

\section{Marine environment quality assessment}

National technical regulation on marine water quality (QCVN 10-MT:2015/BTNMT) [14] is used to access the seawater quality. All heavy metal concentrations were lower than the permitted values. Therefore, seawater environment from Nga Son to Cua Hoi (0-30 m water depth) was not polluted by heavy metals (table 5).

ISQGs [16] and QCVN 43:2012/BTNMT [15] are used to access sediment quality. Concentrations of $\mathrm{Cu}, \mathrm{Pb}, \mathrm{Zn}, \mathrm{Sb}, \mathrm{As}$ and $\mathrm{Hg}$ were all lower than the permitted values of the
QCVN 43:2012/BTNMT and ISQGs, indicating that marine sediments from Nga Son to Cua Hoi $(0-30 \mathrm{~m}$ water depth) were not contaminated by these heavy metals (* [17], ** [14], table 6).

The concentrations of total OCPs and PCBs did not exceed the TEL threshold of ISQGs and were still lower than the permitted values of the QCVN 43:2012/BTNMT (table 6), reflecting that the marine sediments of the study area were not polluted by OCPs and PCBs compounds.

Table 5. The average concentrations ( $\mathrm{mg} / \mathrm{l})$ of selected heavy metals in seawater from Nga Son to Cua Hoi $(\mathrm{n}=127)$ and their permitted values by QCVN 10:2015/BTNMT

\begin{tabular}{|c|c|c|c|c|c|}
\hline \multirow{2}{*}{ Element } & \multirow{2}{*}{ Ocean world* } & \multicolumn{3}{|c|}{ QCVN 10-MT:2015** } & \multirow{2}{*}{ Nga Son - Cua Hoi sea } \\
\hline & & Beach & Aquaculture & Other & \\
\hline As & 0.003 & 0.04 & 0.02 & 0.05 & 0.0037 \\
\hline $\mathrm{Cd}$ & 0.0001 & 0.005 & 0.005 & 0.01 & 0.00020 \\
\hline $\mathrm{Pb}$ & 0.00003 & 0.05 & 0.05 & 0.1 & 0.00036 \\
\hline $\mathrm{Cu}$ & 0.003 & 0.5 & 0.2 & 1 & 0.0039 \\
\hline $\mathrm{Zn}$ & 0.01 & 1.0 & 0.5 & 2.0 & 0.019 \\
\hline $\mathrm{Mn}$ & 0.002 & 0.5 & 0.5 & 0.5 & 0.0034 \\
\hline $\mathrm{Hg}$ & 0.00003 & 0.002 & 0.001 & 0.005 & 0.00004 \\
\hline $\mathrm{Sb}$ & 0.0005 & - & - & - & 0.000052 \\
\hline
\end{tabular}


Table 6. The average concentrations $\left(10^{-3} \%\right)$ of heavy metals in marine sediments from Nga Son to Cua Hoi $(n=524)$ and their permitted limit values by ISQGs and QCVN 43:2012/BTNMT

\begin{tabular}{|c|c|c|c|c|c|c|c|c|}
\hline & Pollution level & Standard & $\mathrm{Cu}$ & $\mathrm{Pb}$ & $\mathrm{Zn}$ & $\mathrm{Sb}$ & As & $\mathrm{Hg}$ \\
\hline Ocean w & Iorld & & & & & & & \\
\hline Potential & & $>3^{*} \mathrm{TBTG}$ & & & & & & \\
\hline & Weak & $>$ Tel & 1.87 & 3.2 & 12.4 & - & 0.724 & 0.013 \\
\hline & Average & $>1.5^{*} \mathrm{Tel}$ & 2.81 & 4.8 & 18.6 & - & 1.086 & 0.0195 \\
\hline ISQGs & Strong & $>2 *$ Tel & 3.74 & 6.4 & 24.8 & - & 1.448 & 0.026 \\
\hline & Very strong & $>3^{*} \mathrm{Tel}$ & 5.61 & 9.6 & 37.2 & - & 2.172 & 0.039 \\
\hline & Influence level & $>\mathrm{Pel}$ & 10.8 & 11.2 & 27.1 & - & 4.16 & 0.0696 \\
\hline QCVN 4 & 3:2012/BTNMT & & 10.8 & 11.2 & 27.1 & - & 4.16 & 0.07 \\
\hline Nga Son & - Cua Hoi Sea & & 0.34 & 0.50 & 0.59 & 0.024 & 0.08 & 0.006 \\
\hline Pollution & level & Standard & PCBs & 44DDE & 44DDD & 44DDT & & \\
\hline Ocean w & Iorld & & - & - & - & - & & \\
\hline Potential & & $>3^{*}$ TBTG & - & - & - & - & & \\
\hline ISQGs & Weak & $>$ Tel & 21.5 & - & - & - & & \\
\hline & Average & $>1.5^{\star} \mathrm{Tel}$ & 32.25 & - & - & - & & \\
\hline & Strong & $>2{ }^{*} \mathrm{Tel}$ & 43 & - & - & - & & \\
\hline & Very strong & $>3^{*} \mathrm{Tel}$ & 64.5 & - & - & - & & \\
\hline & Influence level & $>\mathrm{Pel}$ & 189 & - & - & - & & \\
\hline QCVN 4 & 3:2012/BTNMT & & 189 & 7.8 & 374 & 4.8 & & \\
\hline Nga Son & - Cua Hoi Sea & & 6.97 & 0.04 & 0.17 & 0.28 & & \\
\hline
\end{tabular}

\section{CONCLUSIONS}

Surface sediments of Nga Son to Cua Hoi sea (0-30 $\mathrm{m}$ water depth) were composed of fine- to coarse-grained sizes. The high absorbed capacities of sediments to toxic substances were mainly distributed from $10 \mathrm{~m}$ to $30 \mathrm{~m}$ water depth. Seawater environment was characterized by neutral-weak oxidation in layer from 0-10 $\mathrm{m}$ in depth and weak alkalineweak oxidation in layer from $10-30 \mathrm{~m}$ in depth and strongly influenced by freshwater from river estuarine systems. Major anions and elements in seawater had tendency to decrease with depth, from nearshore to offshore regions, except for $\mathrm{Mg}, \mathrm{B}, \mathrm{Br}$ that had the opposite trend. Sediment environment was characterized by neutral-strong oxidation in $0-10 \mathrm{~m}$ water depth region and weak alkaline-weak oxidation in 10-30 $\mathrm{m}$ water depth region. The major anion $\left(\mathrm{SO}_{4}{ }^{2-}, \mathrm{PO}_{4}{ }^{3-}, \mathrm{NO}_{3}^{-}, \mathrm{CO}_{3}{ }^{2-}\right)$ and heavy metal concentrations in marine sediments were higher in fine-grained sediments and in the middle of study area. PCBs tended to gradually increase from north to south, but $\mathrm{HCHs}$ and DDTs tended to have an opposite trend. According to the seawater and marine sediment quality guidelines of Vietnam and Canada, the seawater and marine sediments were not polluted by heavy metals $(\mathrm{Cu}, \mathrm{Pb}, \mathrm{Zn}, \mathrm{Sb}, \mathrm{Hg}$, As), PCBs and OCPs.

Acknowledgements: This paper is completed in the framework of the project "Investigation of geology and mineral of coastal zone from Nga Son to Quang Thai (0-30 m water depth), scale 1:100,000 - 1:50,000". We would like to extend special thanks to the Marine Natural Resources - Environment Survey Center staffs for all logistic supports during field sampling.

\section{REFERENCES}

1. HELCOM, 2007. Heavy metal pollution to the Baltic Sea in 2004. HELCOM Balt. Sea Environ. Proc. No. 108, 33p.

2. Valavanidis, A., and Vlachogianni, T., 2010. Metal pollution in ecosystems. Ecotoxicology studies and risk assessment in the marine environment. Sci. Adv. Environ. Toxicol. Ecot. Issues. chem-toxecotox. content/uploads/2010/01/02-Metalsorg/wp/wp17_01_2010.pdf[on line]. 
3. Naser, H. A., 2013. Assessment and management of heavy metal pollution in the marine environment of the Arabian Gulf: a review. Marine pollution bulletin, 72(1), 6-13.

4. Aderinola, O. J., Clarke, E. O., Olarinmoye, O. M., Kusemiju, V., and Anatekhai, M. A., 2009. Heavy metals in surface water, sediments, fish and Perwinklesof Lagos Lagoon. Am.-Eurasian J. Agric. Environ. Sci, 5(5), 609-617.

5. Esslemont, G., 2000. Heavy metals in seawater, marine sediments and corals from the Townsville section, Great Barrier Reef Marine Park, Queensland. Marine Chemistry, 71(3), 215-231.

6. Vizzini, S., Costa, V., Tramati, C., Gianguzza, P., and Mazzola, A., 2013. Trophic transfer of trace elements in an isotopically constructed food chain from a semi-enclosed marine coastal area (Stagnone di Marsala, Sicily, Mediterranean). Archives of environmental contamination and toxicology, 65(4), 642-653.

7. Hedges, J. I., Clark, W. A., and Come, G. L., 1988. Organic matter sources to the water column and surficial sediments of a marine bay. Limnology and Oceanography, 33(5), 1116-1136.

8. Glasby, G. P., and Schulz, H. D., 1999. Eh $\mathrm{Ph}$ diagrams for $\mathrm{Mn}, \mathrm{Fe}, \mathrm{Co}, \mathrm{Ni}, \mathrm{Cu}$ and as under seawater conditions: application of two new types of eh ph diagrams to the study of specific problems in marine geochemistry. Aquatic geochemistry, 5(3), 227-248.

9. Addo, M. A., Okley, G. M., Affum, H. A., Acquah, S., Gbadago, J. K., Senu, J. K., and Botwe, B. O., 2011. Water quality and level of some heavy metals in water and sediments of Kpeshie lagoon, La-Accra, Ghana. Research Journal of Environmental and Earth Sciences, 3(5), 487-497.

10. Buccolieri, A., Buccolieri, G., Cardellicchio, N., Dell'Atti, A., Di Leo, A., and Maci, A., 2006. Heavy metals in marine sediments of Taranto Gulf (Ionian
Sea, southern Italy). Marine

Chemistry, 99(1), 227-235.

11. Ip, C. C., Li, X. D., Zhang, G., Wai, O. W., and Li, Y. S., 2007. Trace metal distribution in sediments of the Pearl River Estuary and the surrounding coastal area, South China. Environmental Pollution, 147(2), 311-323.

12. Wang, S., Jia, Y., Wang, S., Wang, X., Wang, H., Zhao, Z., and Liu, B., 2010. Fractionation of heavy metals in shallow marine sediments from Jinzhou Bay, China. Journal of Environmental Sciences, 22(1), 23-31.

13. Majer, A. P., Petti, M. A. V., Corbisier, T. N., Ribeiro, A. P., Theophilo, C. Y. S., de Lima Ferreira, P. A., and Figueira, R. C. L., 2014. Bioaccumulation of potentially toxic trace elements in benthic organisms of Admiralty Bay (King George Island, Antarctica). Marine Pollution Bulletin, 79(1), 321-325.

14. MONRE, 2015. National technical regulation on water quality (QCVN 10:2015/BTNMT). Vietnam Ministry of Natural Resources and Environment, Hanoi.

15. MONRE, 2012. National technical regulation on water quality (QCVN 43:2012/BTNMT). Vietnam Ministry of Natural Resources and Environment, Hanoi.

16. CCME, 2002. Canadian sediment quality guidlines for the protection of aquatic life: Summary tables update, In: Canadian sediment quality guidelines, 1999. Canadian Council of Ministers of the Environment.

17. Mai Trong Nhuan, 2006. Environmental Geochemistry. Vietnam National University Press, Hanoi. (In Vietnamese).

18. MOST, 2008. Determination of biochemical oxygen demand after $\mathrm{n}$ days (BODn) - Part 1: Dilution and seeding method whith allylthiourea addition. Vietnam Ministry of Science and Technology, Hanoi. 
Characteristics of marine environmental...

19. MOST, 1999. Water quality - Determination of the chemical oxigen demand. Vietnam Ministry of Science and Technology, Hanoi.

20. MOST, 2000. Soil quality - extraction of trace elements soluble in aqua regia. Vietnam Ministry of Science and Technology, Hanoi.
21. Dao Manh Tien, 2009. Research on the potential accumulation of pollutants in coastal sediment in Vietnam. Marine Natural Resources - Environment Survey Center, Hanoi. 